\title{
WEAK STATE INSTITUTIONS AND INSURGENCY ORIGIN IN IRAQ: A CASE STUDY OF MALIKI'S ERA
}

\author{
Muqaddas Khan*, Ahmad Ali $\uparrow$ \& Jawad Khan Shinwarił
}

\begin{abstract}
Emergence of Islamic State (IS) in Iraq has forged havoc in country. Unlike other radicalist groups, IS is the product of socio-political and institutional nuisance, rather to be ignited by ethno-religious fracas. This paper is aimed to analyse the relationship between state institutions and society; how weak state institutions facilitate the genesis of insurgency; and how the institutional malaise created grounds for insurgency to infiltrate in Iraq? The American intervention of Iraq eroded the state vital institutions. Henceforth, the democratic transition under Maliki's administration, despite of establishing national unity, hatched ethno-sectarian cleavage in society. Maliki's proclivities of centralization and immature culture of political parties in running the affairs of parliament alienated the Sunni community in Iraq. Moreover, the American perception of Sunni community under Saddam Hussein further inflamed the communal discord. Such bias culminated mass exodus on the pattern of communal and sectarian bases from Bagdad to other regions of the country. Once, the ground was set for resentment against other sects, ethnicities and state, then it was easy for radicalist groups to exploit the deprived communities accordingly.
\end{abstract}

Keywords: US, Iraq, Islamic State, State Institutions, Insurgency, and Arab Spring.

\section{Introduction}

The US led intrusion of Iraq in the name of denuclearization dismantled the state institutions premised on nationalism and Arabism under Ba'th

\footnotetext{
M.Phil, International Relations, graduate from International Islamic University, Islamabad.

Lecturer, Political Science, Higher Education Department, Peshawar, KPK.

M.Phil, IR graduate from IIUI \& Research and Content writer Dr. Moeed Pirzada's team, GNN-TV.
} 
party. The institutional turmoil prolonged the armed resistance causing a social rupture which created chaos of identity crises in the unfortunate Iraq. The US occupation of Iraq was even more resented when government formation patternized administration on sectarian lines. Obviously Americans were trying to implement the democratic structure in the country but, once ignite sectarianism in the society, then, how one could revive the culture of democracy? ISIS was not in position to with hold the position in the region, if the Sunnis were kept aloof from it. Since the so-called democratic transition offered fragmentary and contradictory policy toward different seats and ethnicity, the Kurd's, Shia and Sunni choose different path (Biddle, 2008). It is necessary to note that the synopsis of life under the self proclaimed caliphate of ISIS is not good enough but so far Sunnis were getting recognition and their rights, they are willing to sacrifice certain bitterness. (University, 2016)

The democratic transition in Iraq, despite of securing and creating strong institutions, muscled out the ignorant and immature masses, exploited by extremist elements and regional cum global proxies. Generally, the Middle East pandemonium (Iraq and Syria) was the result of American struggle for democratic transition from 2003 to 2007. The Iraq intrusion derailed the security institutions in the country there-by leaving the law and order situation of common masses to the blessing of Hobbesian state of nature. American immaturity, chasing insurgents and terrorists around the sand rather than focusing on institutions re-construction for law and order assurance, alienated the vast bulk of Euphrates and Trigis clans. The natural outcomes of security vacuum, war of all against all, were unorganized burglary, revenge killings, rampant looting and kidnapping (Pollack, 2013). The state of confusion went apart in Iraqi society, partly due to regional and global proxies and assumed the shape of bigots, haters, and people eagerness to kill someone for the simple reason of not being one of their own; and, the ethno-sectarian chauvinists. The concept of state as society at general was deteriorated there-by enforcing the pre-civilization concept of clanship and family tribalism (Yamashita, 2005).

Although the genesis of insurgency especially Islamic State in Iraq has been mentioned in Middle Eastern political debates, but the emergence of Islamic State in relations with state vital institutions has not been specified. Thus previous research lack the direct co-relations of Iraq vital state institutions and their weal performance in aggravating belligerent movement especially Islamic State. This paper uses Haroro J. Ingram framework of "Four Dimensional Model of Insurgency" to comprehend the role of Iraqi parliament, executive body and political parties in provoking antagonism in different fictions of society. This paper indentify that the structure and function (two pillars of Four Dimensional Model of Insurgency) of aforementioned three vital Iraqi-state institutions are responsible for 
deteriorating political situations which in consequent welcomed insurgency especially Islamic State footing inside country.

\section{Methodology and Implications of Four Dimensional Model of Insurgency}

Many scholars have viewed the emergence of Islamic State in Iraq with different perspectives of external and internal dynamics. This paper contemplates three basic institutions of Iraq i.e. parliament, executive body and political parties in comparison with genesis of insurgent movement of Islamic State. Moreover, this paper follows simple descriptive analysis approach. An institutions is defined as "the rule of game in a society or, more formally, that they are humanly devised constraints that shape human interaction. As a consequence, they structure incentives in human exchange whether political, social, or economic" (Herrera, 2005). Similarly, insurgency is defined as "a multi-dimensional campaign, typically embarked upon by non-state actors that strategically use violence often against state actors, that is designed to influence, if not completely change the mechanisms and structures of power that exert influence over a contested population" (Ingram, 2012).

Table 1: Methodology - Relations between Direct and Indirect Variables

\begin{tabular}{|l|c|c|c|}
\hline \multicolumn{2}{|c|}{ Direct Variables } & \multicolumn{2}{c|}{ Indirect Variables } \\
\hline State Institutions & Insurgents & Leadership & Period \\
\hline $\begin{array}{l}\text { Parliament } \\
\text { Executive } \\
\text { Political Parties }\end{array}$ & Islamic State & Nouri al-Maliki & $2006-2014$ \\
\hline
\end{tabular}

'Four Dimensional Model of Insurgency' presented by Haroro J. Ingram implies that each of the four dimensions - structural, functional, military and, perception and polarization - are reflective mechanisms of state power which underscores the power of insurgent movement, if executed properly. In contrast, the mal-functioning of these pillars can also contribute to the emergence of insurgent movements. In this paper the pillars of structure and function are contested against three above mentioned vital institutions of Iraq during Maliki's era which welcomed Islamic State to emerge. The structural pillar of the model refers to the political infrastructure of a state or insurgent movement. The dimension of structure recognizes constitution, judicial/legal system, law enforcement agencies and financial markets of a given setup. The functional pillar of the model refers to the processes through which established authority maintain order. The dimension of function includes the use of coercion/force where needed, maintain law and 
order, mediation/control of civil disputes, collection of taxes or revenue generation and identity preservation of particular population.

Table 2: Implication of Four Dimensional Model of Insurgency

\begin{tabular}{|l|l|}
\hline \multicolumn{2}{|c|}{ Four Dimensional Model of Insurgency (Contested Variables) } \\
\hline \multicolumn{1}{|c|}{ Structural Dimension } & \multicolumn{1}{c|}{ Functional Dimension } \\
\hline Constitution & Use of coercion/force \\
Judicial/Legal System & Maintain law and order \\
Law Enforcement agencies & Mediation of civil disputes \\
Financial Markets & Collection of taxes \\
& Identity preservation \\
\hline
\end{tabular}

\section{Thematic Literature Review}

\section{(a) Deconstruction of Iraq (2003)}

The prolonged US sanctions throughout 1990s facilitate the gradual degradation of the Iraqi-regime. For-instance the writ of central government lost legitimacy on each passing day, there-by weaken the state pillars (institutions) - civil and military bureaucracies, civil societies, businesses enterprises and social fabrics of Iraq (Hinnebusch, 2007). US support for Kurdistan movement which existed well before sanctions were imposed and had has devastative effects on sectarianism, further strengthen the disquiet (Afzal, 2017).

In Iraq, drastic social changes were witnessed at domestic level when US nuclear venture destabilized the state institutions especially national security institutions. The exclusion of security institutions in Iraq disturbed the decade's old constructed phenomenon of social balance between different ethnicities and sects (Curtis, 2017). Consequently, sense of social alienation has been infused among Sunni's and Kurd's communities. Once the social vacuum created, it was easy for Sunni radicalist to forge a fault line in society and subsequent infiltration into country's affairs. To counter the dilemma, US military empowered and facilitated the local tribes against radicalist groups (Hinnebusch, 2014). The strategy scored well in early years of US stay in Iraq. However, US military paid no attention to Shi'a militias activities especially "when they were capturing the reconstructed military and other security forces" in Iraq which completely alienate the Sunni community in terms of social security and identity. Obviously, US was presurrounded by certain strategic goals of countering Russian influence in Levant; facilitating Israel against regional odds; and oil politics which restricted her to do so. Similarly, there is no-denial to the fact that US move of Iraq intrusion itself was strategic in nature rather to be assumed as antinukes mission (Bassil, December 2012). 


\section{(b) Post-US Iraq, Arab Spring and Genesis of IS}

The autocratic regimes of Egypt, Tunisia, Libya and Yemen had been hacked-off from their offices after 126 years of long rule. The Assad's 40years regime is struggling against popular demand, whether true or other way around is a matter to be discussed, but western perceived, it is a menace for democratic ideas (Hakala, 2013). The "December 2010 winter" (Arab uprising) has the capacity to wash-away the so called authoritarian malaise. The bloody and relentless civil wars in Arab states (Arab uprising) had/has spell-over effect on Iraq reconstruction as well. The American occupation of Iraq and the process of institution building receives are set-back when massive -widespread riot, demonstration and protest shaken the neighbour authoritarian regions (Bassil, 2012). The most confusing and complex question come to everybody mind was/is: if the Arab uprising was/is aimed at uprooting the authoritarian regime and executing or installing the democratic values and government structure in one's country and Americans were formulating the democratic culture in Iraq then why did Iraq faced the similar fate?. To blame westerns and regional proxies it would be unjust with topic. Writer focused the political and institutional development and its role in the emergence of ISIS in Iraq (Glenn, 2018).

\section{(c) Nature of the uprising (Arab Spring)}

In a comparative manner, the Arab uprising in Iraq was somewhat different from the other Arab countries where the mass demonstration was aimed of toppling the regime and to replace with new faces. Mass demonstration in Iraq unlike Arab countries, was aimed at improving the governmental functions of Prime Minister Nouri al Maliki which had been installed for more than six years (Itani, 2014). The demonstrations in Iraq compared to other Arab countries were small and mostly lacked the capacity of destabilizing the government at all with distinguished goals, i.e. free and fair elections;improving the abysmal functions of elected Maliki's government;re-assessing his failure in delivering the social service (water, food, electricity and health etc); (Khan, 2018) the mal-functions of parliament both in formulating laws and their execution especially in fields of corruption, nepotism and ethno-sectarian harmony; and, the attitudes of civil officers towards common man which was more like master and slave in nature. Moreover, the protestors in Tunisia, Egypt Libya and Yemen were so frustrated that they were willing to put their lives to achieve the rights from constitutional monarch. In comparison the Iraq demonstration was less radical in nature since they had already obtained certain rights after the ousting of Saddam Hussein. Hence, the struggle was less radical in nature. (Dawisha, 2012)

Nothing was wrong with the process of election or embracing the democratic values and practices. The problem was, putting someone in the position of premiership through democratic process is one thing, but how he 
behaves or whether he behaved democratically, is the belief on the notion of concession and compromise. The basic ingredient of democratic culture seemed unpredictable at the root level (Mansour, 2017). The process of 'check and balance' another essential element of democracy, in Maliki's administration portrayed the image of forceful monarch imposition despite of conducting for the purpose of eradicating corruption and other related evils from bureaucracy and administrations (Shinwari, 2018). Similarly, the recruitment of government officials by the process of competition was halted at first place; and if some officials by any chance, got the offices was in no position of dealing common masses. Most importantly the formula of Power sharing between different ethnicity, sectarian groups, and hierarchical positions of Saddam's officials were arranged in a way that another civil war was inevitable (Pollack, July 2013).

\section{Nature of Iraqi Elections (December 2005 and March 2010)}

The demographic profile of Iraq shows, 60\% Shia Arabs, 20\% Sunni Muslims and 17\% Non Arab Kurds which inhabit the country. In December 2005 general election the al-Iraqiya under the leadership of Ayad Allawi, the only secular and non-ethnic political group, received a great shock which hardly secured 8 percent seats in National Assembly. Dawa party (Shia based party) under Maliki won almost 50 percent of seats in National Assembly (Khan, 2018). The elections result showed that country's politics was based on the footing of sectarian lines. However, country's national integrity was assured despite of ethno-sectarian differences. The problem started when Dawa party for almost two years kept herself busy in coalition formation with Shia's politicians. The miseries of Sunni communities were put in second priority which germinates the seed of conflict at society level (Hakala, 2013). Democracy being an alien and new concept to society was presumed as struggle for number game rather to represent common masses which created ethno-sectarian havoc.

The February 2006 bombing in holly mosques of Shia dragged the country into bloody civil war, until the 2008 Arab Spring started. Maliki's administration came under extreme pressure and launched counterinsurgency operation in order to de-tack the Al-Qaeda from Sunni Muslim tribes. In addition, Maliki's success was also considered in defeating the Mahdi Army (Shia based militant group which has taken the control of Basra and Sadr cities) and creed the Sadr city. Maliki's administration also denounced sectarian based politics and became the advocate of nationalism by setting the foundation of state of the law (SOL) party. In 2009, local elections, SOL secured victory in 9 out of 14 provinces (Bassil, 2012).

An idea which articulated among Western writer that destabilization in Iraq is based on bitter fact of minority (Sunnis) role over majority (Shias) during Saddam Hussein seems slackening. Adeed Dawisha expressed his 
views: " The 2010 elections and its eye-opening results cannot be understood without an appreciation of the political development in Iraq since the forcible ouster of Saddam Hussein, throughout the country history a Sunni Arab minority had monopolised Political powers over a Shia Arab majority and a non Arab Kurdish community" (Dawisha, 2012). The victory of SOL in 2009 local elections is a factwhich negates the western claim of democratic norms. The US quest for democracy despite of reducing the gaps between different sects, further intensify the cause because when it comes to national unity, the Pan-Arabism concept for last few decades had best served the country.

Importantly, instead of constructing a balance approach between Sunnis, Shias and Kurds, US once again in 2010 election, blindly supported Nouri al-Maliki's flawed government policies. In addition, US policy maker also mis-managed the regional power matrix in co-relevance with Iraq's neighbours. For-instance, Nouri al-Maliki's pro-Iranian policy was assumed critically by Saudi Arabia and US and considered the regime as the formerproxy in Levant. Resultantly, Lebanon and Iraq became battle ground for radical groups which has direct impacts on national security and integrity. Ultimately, it ignites the Kurdistan movement in Iraq which compelled Turkey to intervene in country's internal politics (Afzal, 2017). Turkey extended help toIraqiya party under Ayad Allawi, a trans-sectarian secular party of Iraq, in2010 election against Maliki's premiership. Iraqiya (Allawi), despite of having majority did not succeed in making government, because Muqtada al Sadr's Shi'a party was convinced by Iran for supporting Maliki's regime. Similarly, US also persuaded Allawi for coalition government under Maliki's premiership.

The idea of coalition seems convincing that both sect's would unite, but the intension here is contradiction. Since it is a known fact that US would not allow a stable Middle East because it requires minus American strategy, the coalition was a move to set future discontent portraying an image of British imperialism after WWI. On the other-hand, the support of transsectarian movements by regional stake-holder (Iran and Turkey) seems unfair for the time being but in longer-run, it will provide ground for both sects to create a balance between them (Hinnebusch, 2007).

Interestingly, the election result of March 7, 2010 showed some maturity and confusion as well. Secular Al-Iraqiya won, followed by SOL and subsequent sectarian and ethnic parties. Once again, the sectarianism was not the people choice rather it was enforced to society i.e. strong institutions for national representation, a basic prerequisite of democracy, were sidelined for sectarian and ethnical purposes which ignite the wave repression and animosity (Hakala, 2013). 


\section{Maliki's Ineffective Parliament}

Since, Al-Iraqiya won the election, Maliki's considered the failure as revenge or may be how to perform the duty of opposition was lacking in the Iraqi political culture because it was something alien. The results were dismissed and recounting decision was issued by court. Maliki's through the power of his office compelled the court for recounting and later on pressuring supreme federal court to interpret the constitution in his favour. Yet again, court as an independent institution failed to deliver its constructive role in streamlining the state affairs. The court decreed that if an alliance with higher number of seats came against the winning party (AlIraqiya) it would forfeit the right of forming government (Curtis, 2017). AlIraqiya was distracted in challenging the court interpretation (Mansour, 2016). The court jurisdiction and the role of executive in Higher Independent Electoral Commission (HIEC) supported Maliki's stance. Government got engaged in finding partners, gave and take policies. Maliki's concession and promises and even tried to merge the Sunni and Shiite to get majority Seats in National Assembly provided opportunity to radicalist groups to infiltrate deep in society. The merger would have be a great success of Maliki's since he was considering himself a nationalist but deep down he remained a sectarian at heart and formed new Shiite alliance.(Dawisha, 2012)

Now having the majority Seats in National Assembly, Maliki's was set to from the government, but to execute it on to run it smoothly he need a larger coalition.To such extent, Jalal Talabani, Iraq's president and Masoud Barazani, President of autonomous region of Kurdistan were approved by Maliki's but they insisted to share power equally i.e. National unity Government (Fearon, 2007). A parallel executive structure for national government was proposed i.e. the 'Council for Strategic Policies' (CSP) In December Maliki's decided to accede the proposal and form the government.

The election and formation of government almost took two months along with administrative and political paralysis and drudgery. Still, people were hoping for the betterment of institution and decentralization of their power and functions. Immediately after taking office of Prime Minster ship Maliki passed degrees and brought the supreme federal court under Prime Minister Office's (Itani, 2014). The purpose of the move was to get control of the other institutions with the help of court. Further centralization started in January 2011, when court ruled that independent commissions and committees for conducting election, corruption and accountability, human rights and central bank should be kept under the Prime minister control. (Dawisha, 2012)

The ingrained penchant of Maliki for consolidating power into his own hand and did not stopped and pressured court to attach the HIEC under Prime Minister Office. Judges mostly Maliki's minions, issued the most 
egregious degree with convoluted argument that placing HIEC under legislative branch of government is violation of the democratic phenomenon of separation of power. Henceforth, Saleh Mutlaq, the deputy prime minister, considered Maliki's a Dictator by placing the argument that how an independent HIEC can work under these circumstances. In response Maliki's accused Saleh Mutlaq as traitor against the country's and community political journey and, dispatched the armoured tanks, once again repeated the memories of Pre-Napoleon Western societies (Khan, 2018). Similarly, Maliki was also criticised by Mutalaq's of Al-Iraqiya for misplacing and torturing thousand of party members and supporters in order to obtain a forceful confession that their party leader was involved in terrorist activities. Indeed, one of such confession compelled Tareq alHashemi, the country's vice president to flee to Kurdish region, when Maliki issued an arrest warrant (Shinwari, 2018). Tareq al-Hashemi asked that he is willing to appear before law but in Baghdad because he knew what happened with Mutlaq, execution without trial. However, Maliki's issued a statement that "we gave Saddam a fair trial and we will give Hashemi a fair trial too" which forged a sense of insecurity among different political parties. In short, the state intuitions whether political or public institution were struggling between the dilemma of authoritarianism and democratic norms which facilitated another bloody insurgency in the shape of ISIS (Hakala, 2013).

\section{Government of National Unity or National Disunity}

Along with Maliki's authoritarian proclivities and personal penchant for power the factor of diverse ethnic and political structure of the country was key cause to turmoil. Since the country's demographic profile consisted of huge member of columns and rows, it was countered by pan-Arab tendencies during Saddam regime. The communal balance under panArabism was based on compromised and collective state interests until; American occupation shifted the beauty of diversity to diversity of blood and haltered (Pollack, 2013). Trump's administration during 2018 meeting with Emmanuel Macron the French president, issued that we (Americans) have spend a lot of money which should be repaid by these countries (Iraq and Syria). The question here come to our mind is, whether these countries (Iraq, Syria and many other) asked you to come and destroy our countries in the name of so-called democracy, human rights and humanitarian assistance? Secondly, what is the equation of destruction vs investment? Is the investment exceeding the destruction? Third, Are the investment and attacks are for purpose? Forth, how you (Mr. Trump) weight the value of human life losses and investment?

It is under these circumstances that Maliki's formed a factious cabinet of 45 members. Usually the government seemed to be of national unity, but to 
promulgate its policies of national development plans, foreign policy, defence and their execution, was arduous and time consuming. Multitude of decisions and policies are, when not reached on time, created a havoc for social, economic and defence sectors, there by further facilitating the haltered between cabinet ministers (Khan, 2018). Despite of working in collective fashion, cabinet ministers engage themselves in delaying and sabotaging the other ministers' ideas and policies just for political rating. The second term of Maliki's in comparison with Haider Jawad kadhim AlAbadi (since 2014) was more focused on consolidating and centralizing power into his own hand which certainly expedited the sectarian cleavage in society (Shinwari, 2018).

\section{Incoherent Political Parties}

If the menace of Maliki's authoritarian penchant and American invasion are some indicators of fragility in Iraq's democratic transition, the incoherent political parties and a do-little parliament are other. The rambling nature of political parties in Iraq along withsocial resentment also appreciated the culture of corruption which ignited the menace of financial gap in diverse community. During the process of democratic transition neither a single political party nor political personality was capable of conducting governmental duties. The concept of opposition party was lacking in parliament (Simon, 2015). Moreover, when it comes to coalition, it required an agreed agenda for smooth conducting administrative functions but coalition under Maliki's was something strange in politics. For instance Dawa party and the Shiite alliance brought Ammar-al-Hashim and Muqtada al-Sadr under Maliki's umbrella. Unlike the marriage of convenience, both clerics were conducting their own policies and negotiations, as both belong to rival families. Maliki's agreed with American forces further stay in Iraq while Al-Sadr rejected the agreement and threatened them that any stay of "Occupiers" and they will wage a guerrilla war. Similarly, secular Al-Iraqiya under Allawi's leadership was also facing the enunciated political agenda or ideology (Khan, 2018). The arrest warrant of the country vice president Tariq al-Hashemi was a test for Al-Iraqiya unity. The party members at first decided the boycott of parliament and cabinet but soon the individual interests ashamed the unity. The coalition also divided in two groups of white Iraqiya and Tajdid (Renewal).

As neither political coalition nor political personalities were able to fit the bill, the function of the parliament was even much distasteful. Since, council for strategic policies (CSP) was formulated in 2010 at Irbil (Kurdish city) as a parallel institution to cabinet under Ayad Allawi leadership, in order to reach an understanding for national unity government formation; Maliki's deliberately boycotted its meetings (Dawisha, 2012). On the contrary, Al-Iraqiya started complaining and boycotting Parliament sessions. 
Most of the government time was spent in boycotting one another meetings and parliament sessions. Consequently it affected the routinely function of state machinery leaving behind general masses on the blessing of radical groups to exploit. Another confusion which appeared before Parliamentarians was the composition and structure of government, division of power exercise and, duties and functions of officials. For-instance, legislature was performing the executive jobs and vice versa. (Dawisha, 2012)

The fragmented and incompetent parliamentary setup had atrocious effects on bureaucracy. Policies without direction from higher authorities and its implementation at grass-root level were almost impossible. Since, accountability and transparency which is usually executed from above was absent in the Iraqi democratic culture, the bureaucrats and government officials were free to do what they want to do. Under such circumstances the only thing which survives comfortable was corruption. In 2011, transparency international ranked Iraq 175th out of 183 countries (Khan, 2018).

\section{Sectarian Discord and Calls for Ethno-Sectarian Federalism}

When the departure of American troops, planned at 2011, approached the sectarian discord began to deteriorate again. As the American backed Maliki's government was accepted by Sunni, al Qaeda operatives began to destabilize the regime and get the assurance of Sunni support for their organization through different tactics. Al-Qaeda mostly targeted the Shia community during their bombing campaign but certain Sunni leaders as well. For-instance during 2007, when a Sunni scholar and law maker denounced Jihad against Baghdad Central Authorities, the venom saved for Sunni, one of al-Qaeda militant blew him in Umm al-Qura aimed at targeting the lawmaker which luckily survived but killed 32 Sunnis and 39 seriously wounded. No-matter what the aim was, the attack re-fuelled the atmosphere of fear and distrust among Sunni and Shia communities (Smith, 2015). Henceforth, the attack was followed by mass migration of families from Baghdad to other districts and outside the country. The tension reached to its peak when post-Qadhafi Libyan leaders informed Maliki that Saddam Hussein military and former Ba'thist members were conspiring the military coup against government. Within few days, up to 600 people were arrested having connection with Ba'th party. A teacher at university of Iraq erstwhile Ba'thist along with 150 other professors was fired off for the same purpose. The move was appreciated by Muqtada al-Sadr "good for us and good for them" further inflaming the sectarian discord (University, 2016).

The result of growing sectarian rift was the exodus of communities to segregated areas. Moreover, the migration pattern was solely based on sectarian and ethnic lines. Such proclivities raise an alarming call for new federating units and even districts within these prevailing units, i.e. power to 
be shifted from Baghdad to districts where local government can perform their functions. The problem was not the transfer of power from centre to units; in reality those new emerged units were based on ethno-sectarian lines, rather, to be based on administrative and territorial lines. The matter of oil share in Basra province (Shia majority) mobilized the movement for autonomous federal status (Khan, 2018). The move was seconded by Anbar, Salah al-Din and Diyala provinces (Sunni majority) where sense of identity crisis, political marginalization and, the belief that community was being treated unfairly and harassed during Maliki's regime was feared. The constitutional injunction and Kurdish definition of autonomous region that not only three provinces of Irbil (as capital and seat of government), Sulaymaniyah and Dohuk but share in non-Kurdish provinces of Salah alDin, Diyala, Nineveh and Kirkuk in Ta'mim province (oil rich region) should be the part of Kurdistan as well. In November 2011, Kurdish government negotiated a deal with Exxon Mobil over oil exploration (Pollack, 2013). The reaction from central government was clear and loud when Deputy Prime Minister for Energy, Hussein al-Shahristani issued a statement that "the Iraqi government will deal with any company that violates the law the same way it dealt with similar companies before". So, it was under such agitation and turbulence circumstances where the ethnosectarian disharmony and dissonance were at peak, the ISIS and other separatist groups cropped up. (Dawisha, 2012)

\section{Critical Analysis: Why Society Accepted the Radicalist Elements?}

Institutional Capacity-lack of National Representation: As mentioned that the transformation of state-based society to pre-civilization clanship brought the culture of preying and slaughtering on communal and sectarian bases. The main problem before regions was the disorganized and increased crime rate and the campaigns of ethnic cleansing by ethno-sectarian militias. Since the institutional functions were limited for securing of specific groups, clan or sect interests, the lack of institutions which represent all the citizens regardless of their communal and sectarian facilitated further the chaos of insurgency. The immaturity on the part of American, to chase terrorists around deserts despite of raising formal and strong security institutions, was followed by regime successions (Assad and militants) as well(Shinwari, 2018). Consolidation of power and creating institutions on communal and sectarian lines subside the national level representative institutions. Policy confusion, flawed process of political settlement and regimeconsistency in repression dumped the national vision of unity and humanity.

Sunni Alienation and Reintegration: The support extended to Sunnis by ISIS was not what it looks like i.e. to drive out the Americans through force from country, but it was part of something bigger. For-instance, they alienated the 
Sunni community in order to be exploit them for manpower and other resources. Though Saddam Hussein was not fair in equal representation of economic and political power among different communities but still his regime was successful in minimizing the tension between them: Pan-Arabism.

Just as what Saddam had done with Americans during his regime, Americans preserved Sunnis as their rival and supported the Shia and Kurd causes instead. The cleavage between different seats went on further widening, when Al-Qaeda and other militant terrorist Jihadist groups won the willingness and eagerness of Sunni to fight against intruders (Americans) and all those who support their cause. To legalize the concept of Jihad, the philosophy of Salafi Jihadism was intoxicated against Shia and Kurd as well (Shinwari, 2018). Resultantly, it completely alienated the Sunni community.(Hinnebusch R. , Spring 2007)

Uprooting Decades Old Social Hierarchy: 'Al-Qaeda in Iraq' (AQI) strategy of recruitment in Sunni community was the lowest on the totem poles then outsiders and other misfit. Arguably creating lords over lords (Sheikhs) and subversion of age-old traditional hierarchy by turning it upside down would disturb the balance in the societal norms and traditions. It is necessary here to mention that the partnership between the Sunni tribal community and Salafi Jihadist in Iraq was not an easy task rather they came close to each other due to mismanagement of power sharing and lack of national institutions for equal representation. Initially, society accepted the new hierarchy system due to its equality factor and way forward to reduce financial gap.

However, soon it was realized that the new social pattern, in practice, is aimed at exploiting personal grievances and revenge killing. The new enforced hierarchy and barbarism in Al-Qaeda realized the Sunnis to whom side they had to choose. 'Sunni awakening' and 'Anbar awakening'especially in Iraq in late 2006 had tremendous application for the new regime. More importantly American also normalized the rigid stance against Sunni awakening and offered them a fair share in political and administrative institution (Hinnebusch, 2007).The re-integration of different communal group in Iraq certainly was a first mile stone of all stake-holders for peace process since the 2003 democratic transition mission. "Sons of Iraq", a new security institution was created composed of Kurds, Shia and Sunni to help the country in consolidating unity and integrity. The new security institution "Sons of Iraq" had/has far-reaching healthy impacts on regime i.e. reduced the bloody antagonism between sects and ethnicity; eradicate the policy of confusion, drawing the line between insurgents and civilians who had/has struggled for right cause and a hope for united Iraq. 


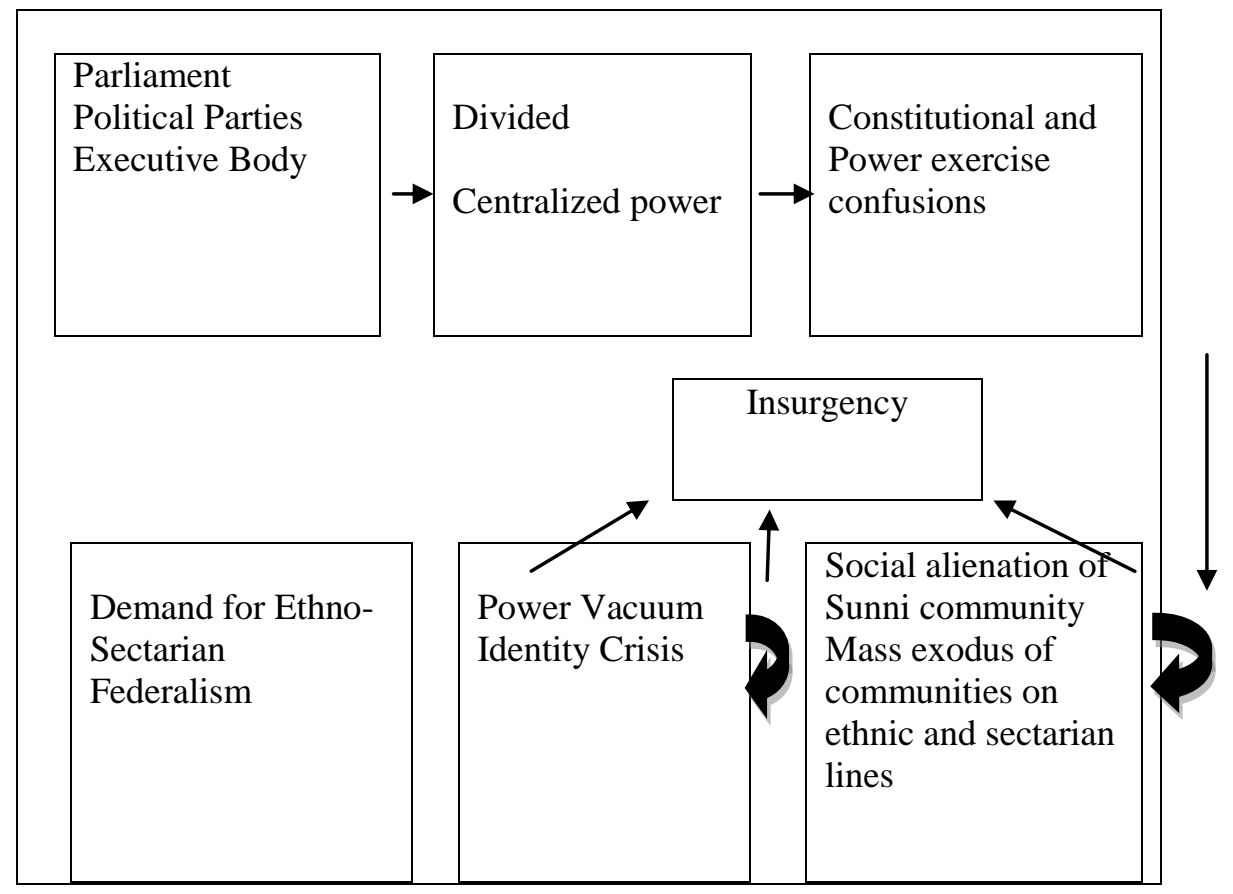

Chart 1: Relationship Between State Institutions and Insurgency Genesis

\section{Conclusion}

The American intrusion of Iraq, primarily destined for anti-nukes mission, has uprooted the state institutions. The post-American Iraq democratic transition start receiving a setback when state institutions and their function depleted from society. American policy of democratic transition in Iraq, despite of building strong state institutions, engaged in chasing terrorist across sands. Similarly, Maliki's administration was more focused on centralization of power and vested interest rather to maintain an institutional harmony which can address the miseries of general masses. Such confusion infused the communal distrust and compelled mass exodus on the pattern of ethno-sectarian lines. Bomb attack against other sects and ethnic groups was adopted by radical elements to exploit the allegiance of Sunni community against Shia and vice versa. Such state institutions failed to address the community identity and basic needs during war time, it was an easy job before radicalist groups to infiltrate in society. It was under such milieu when IS penetrated into Iraq. 


\section{References}

Afzal, A.Q. (2017). Arab Spring: Its Causes And Consequences. Journal of Punjab University Historical Society , 30 (1), 1-10.

Bassil, Y. (December 2012). The 2003 Iraq War: Operations, Causes, and Consequences. IOSR Journal Of Humanities And Social Science (JHSS) , ISSN: 2279-0837, ISBN: 2279-0845. Volume 4, Issue 5, PP 29-47.

Biddle, S. (2008). Stabilizing Iraq from the Bottom Up. Committee on Foreign Relations United States Senate Second Session, 110th Congress.

Curtis, L. (2017). Trump Takes Credit for an Islamic State Defeat Years in the Making. Bloomberg.

Dawisha, A. (2012). Post Occupation Iraq: The Brittleness of Political Institutions. Middle East Program, Woodrow Wilson International Center for Scholars.

Fearon, J.D. (2007). Iraq's Civil War. Foreign Affairs, Vol. 86, No. 2 , pp. 215.

Glenn, R.W. (2018). Illusions of Victory: The Anbar Awakening and the Rise of the Islamic State. Parameters 48(1).

Hakala, P. (2013). Iraq's deadly spiral toward a civil war. DirectorateGeneral for External Policies of the Union Policy Department.

Herrera, P.A. (2005). A Generic Four-Step Methodology for Institutional Analysis of Governance Structures. European Association of Agricultural Economists.

Hinnebusch, P.R. (2014). Syria-Iraq Relations: State Construction and Deconstruction and the MENA States System. LSE Middle East Centre Paper Series 104.

Hinnebusch, R. (2007). The American Invasion of Iraq: Causes and Consequences. Perceptions.

Ingram, H.J. (2012). A Four Dimensional Model of Insurgency and the Centrality of 'Perception and Polarization' to Strategic Success. Small Wars Journal.

Itani, F. (2014). We Must Treat ISIS Like a State to Defeat It. TIME.

Khan, M. (2018). State Institutions and the Genesis of insurgent movement: A case study of "Islamic State" in Iraq and Syria. Department of Politics \& International Relations, Faculty of Social Sciences, International Islamic University, Islamabad.

Mansour, R. (2017). Iraq After the Fall of ISIS: The Struggle for the State. Middle East and North Africa Programme.

Mansour, R. (2016). The Sunni Predicament in Iraq. Carnegie Middle East Center.

Morgan, V. (2016). The Rise of the Islamic State: How the Nouri al-Maliki government set the conditions for the resurgence of Islamic extremism 
in Iraq. Department of Middle Eastern and South Asian Languages and Cultures, University of Virginia.

Pollack, K.M. (2013). The Fall and Rise and Fall of Iraq. Middle East Memo.

Shinwari, J.K. (2018). Role of External Actors in Liquidating State Institutions and Genesis of Insurgency in Syria . Pakistan Journal Peace \& Conflict Studies Volume 3, No.1. Jan-Jun 2018, pp.47-58.

Simon, J.F. (2015). ISIS: The Dubious Paradise of Apocalypse Now. Survival: Global Politics and Strategy 57, no. 3, 7-56.

Smith, B. (2015). ISIS and the Sectarian Conflict in the Middle East. London: House of Commons.

University, P. (2016). Down the Rabbit Hole and into the History of ISIS. Princeton Unversity Press.

Yamashita, H. (2005). The Iraq War, the United Nations Security Council, and the Legitimacy of the Use of Force. NIDS Security Reports, No. 6 , pp. 38-92. 